\title{
Development of a Scar Marker for Pierce's Disease Strains of Xylella fastidiosa*
}

\author{
Regiane F. Travensolo ${ }^{1 * *}$, Luciane P. Ciapina ${ }^{1} \&$ Eliana G. M. Lemos ${ }^{1}$ \\ ${ }^{1}$ Departamento de Tecnologia, Faculdade de Ciências Agrárias e Veterinárias, Universidade Estadual Paulista, \\ Campus de Jaboticabal, Via de Acesso Prof. Paulo Donato Castellane, s/n, CEP 14884-900, Jaboticabal, SP, \\ Brasil, fax: (16) 3209-2675, e-mail: egerle@fcav.unesp.br
}

(Aceito para publicação em 14/10/2004)

Autor para correspondência: Eliana G. M. Lemos

TRAVENSOLO, R.F., CIAPINA, L.P. \& LEMOS, E.G.M. Development of a scar marker for Pierce's Disease strains of Xylella fastidiosa. Fitopatologia Brasileira 30:115-120. 2005.

\begin{abstract}
The objective of this research was to develop a primer for a polymerase chain reaction specific for Xylella fastidiosa strains that cause Pierce's Disease (PD) in grapes (Vitis vinifera). The DNA amplification of 23 different strains of $X$. fastidiosa, using a set of primers REP1-R (5'-IIIICGICGIATCCIGGC-3') and REP 2 (5'-ICGICTTATCIGGCCTAC-3') using the following program: $94^{\circ} \mathrm{C} / 2 \mathrm{~min} ; 35 \mathrm{X}\left(94^{\circ} \mathrm{C} / 1 \mathrm{~min}, 45^{\circ} \mathrm{C} / 1 \mathrm{~min}\right.$ and $72{ }^{\circ} \mathrm{C} / 1 \mathrm{~min}$ and $\left.30 \mathrm{~s}\right) 72^{\circ} \mathrm{C} / 5 \mathrm{~min}$, produced a fragment of $630 \mathrm{bp}$ that differentiated the strains that cause disease in grapes from the other strains. However, REP banding patterns could not be considered reliable for detection because the REP1-R and REP 2 primers correspond to repetitive sequences, which are found throughout the bacterial genome. The amplified product of $630 \mathrm{bp}$ was eluted from the agarose gel, purified and sequenced. The nucleotide sequence information was used to identify and synthesize an specific oligonucleotide for $X$. fastidiosa strains that cause Pierce's Disease denominated Xf-1 (5'-CGGGGGTGTAGGAGGGGTTGT-3') which was used jointly with the REP-2 primer at the following conditions: $94{ }^{\circ} \mathrm{C} / 2 \mathrm{~min} ; 35 \mathrm{X}\left(94{ }^{\circ} \mathrm{C} / 1 \mathrm{~min}, 62^{\circ} \mathrm{C} / 1 \mathrm{~min} ; 72{ }^{\circ} \mathrm{C} / 1 \mathrm{~min}\right.$ and $\left.30 \mathrm{~s}\right) 72{ }^{\circ} \mathrm{C} / 10 \mathrm{~min}$. The DNAs isolated from strains of $X$. fastidiosa from other hosts [almond (Prumus amygdalus), citrus (Citrus spp.), coffee (Coffea arabica), elm (Ulmus americana), mulberry (Morus rubra), oak (Quercus rubra), periwinkle wilt (Catharantus roseus), plums (Prunus salicina) and ragweed (Ambrosia artemisiifolia)] and also from other Gram negative and positive bacteria were submitted to amplification with a pair of primers Xf-1/REP 2 to verify its specificity. A fragment, about $350 \mathrm{bp}$, was amplified only when the DNA from strains of $X$. fastidiosa isolated from grapes was employed.

Additional keywords: oligonucleotide, polymerase chain reaction, PCR, REP-PCR.

\section{RESUMO}

Desenvolvimento de um marcador scar para Xylella fastidiosa causadora do mal de Pierce

O objetivo deste trabalho foi desenvolver um oligonucleotídeo iniciador para reação em cadeia da polimerase (PCR) específico para as estirpes de Xylella fastidiosa que causam o mal de Pierce (PD) em videira (Vitis vinifera). Amplificações de DNA de 23 diferentes hospedeiros, usando o conjunto de oligonucleotídeos REP1-R (5'-IIIICGICGIATCCIGGC3') e REP 2 (5'-ICGICTTATCI GGCCTAC-3') utilizando o programa: $94{ }^{\circ} \mathrm{C} / 2 \mathrm{~min} ; 35 \mathrm{X}\left(94{ }^{\circ} \mathrm{C} / 1 \mathrm{~min}, 45^{\circ} \mathrm{C} / 1 \mathrm{~min} ; 72^{\circ} \mathrm{C} / 1 \mathrm{~min}\right.$ and $30 \mathrm{~s}) 72{ }^{\circ} \mathrm{C} / 5 \mathrm{~min}$, produziu um fragmento de $630 \mathrm{pb}$ que diferenciou as estirpes de videiras dos demais. Entretanto, padrões de bandeamento REP não são considerados confiáveis para detecção devido ao par de oligonucleotídeos REP 1 e REP 2 corresponderem a seqüências repetitivas encontradas por todo o genoma bacteriano. Desse modo, o produto amplificado de 630 pb foi eluído do gel de agarose, purificado e seqüenciado. A informação da seqüência nucleotídica foi usada para identificar e sintetizar um oligonucleotídeo específico para o isolado de X. fastidiosa causadora do mal de Pierce denominado Xf-1 (5'CGGGGGTGTAGGAGGGGTTGT-3'), que foi utilizado juntamente com o oligonucleotídeo REP-2 nas condições $94{ }^{\circ} \mathrm{C} / 2$ min; $35 \mathrm{X}\left(94^{\circ} \mathrm{C} / 1 \mathrm{~min}, 62{ }^{\circ} \mathrm{C} / 1 \mathrm{~min} ; 72{ }^{\circ} \mathrm{C} / 1 \mathrm{~min}\right.$ and $\left.30 \mathrm{~s}\right) 72{ }^{\circ} \mathrm{C} / 10 \mathrm{~min}$. Os DNAs das estirpes de $X$. fastidiosa de outros hospedeiros [amêndoa (Prumus amygdalus), citros (Citrus spp.), café (Coffea arabica), olmo (Ulmus americana), amora (Morus rubra), carvalho (Quercus rubra), vinca (Catharantus roseus), ameixa (Prunus salicina) e ragweed (Ambrosia artemisiifolia)] e de bactérias Gram negativas e positivas foram submetidos a amplificação com o conjunto de oligonucleotídeos Xf-1/REP 2 . Um fragmento, de aproximadamente $350 \mathrm{pb}$, foi amplificado apenas com o DNA de $X$. fastidiosa isolada de videira.
\end{abstract}

Palavras-chave adicionais: oligonucleotídeo, reação em cadeia da polimerase, PCR, REP-PCR.

\section{INTRODUCTION}

Pierce's Disease (PD) in grapes (Vitis vinifera L.) is endemic to the United States wine producing regions. Initially

\footnotetext{
*Parte da Dissertação de Mestrado do primeiro autor. UNESP/Jaboticabal (2000) **Bolsista da CAPES
}

found only on the American continent, stories of its presence in Asia and Europe demonstrate a wider global distribution of this bacterium disease. The causal agent, a Gram-negative bacterium Xylella fastidiosa Wells et al. (Wells et al., 1987) is restricted to the xylem of its host plants and spreads from plant to plant by xylem sap-feeders. In addition to the strain 
that attacks grapes, $X$. fastidiosa also has been detected in a great number of other economically important host plants species, such as alfalfa (Medicago sativa L.), citrus (Citrus spp.), coffee (Coffea arabica L.), peach [Prunus persicae (L.) Batsch], plum (Prunus salicina Lindl) and other forest and ornamental plants (Hopkins, 1989). Several methods have been used to detect the occurrence of $X$. fastidiosa in contaminated plant tissues, including electron microscopy (Rossetti et al., 1990), serology (Chang et al., 1993) and polymerase chain reaction (PCR) (Qin et al., 2001).

Molecular markers such as random amplified polymorphic DNA (RAPD) (Pooler \& Hartung, 1995), arbitraryprimed (AP-PCR) (Costa et al., 2000), restriction fragment lenght polymorphism (RFLP) (Chen et al., 1992), variable number of tandem repeated (VNTR) (Coleta-Filho et al., 2001), repetitive sequence based-PCR (rep-PCR) (Hendson et al., 2001), PCRRFLP (Qin et al., 2001), intergenic spacer (ITS) 16S-23S rDNA sequencing (Hendson et al., 2001), clamped homogeneous electric field - CHEF (Hendson et al., 2001), plasmidial profile (Chen et al., 1992) have been used to study the genetic diversity amongst $X$. fastidiosa strains.

Efficient and economical methods for detection of such pathogen are essential for establishing a quarantine program to adequately screen of contaminated plants with low bacterial population (Purcell \& Hopkins, 1996). Among other available detection methods, the PCR-based markers have been the most widely used in molecular genetic studies as they are simple, quick, flexible and sensitive. One such marker is the SCAR (sequence characterized amplified region) (Karp et al., 1996), which has the advantage of being less sensitive to the conditions of a standard PCR due to its primer size when compared to RAPD. Moreover SCARs have other desirable characteristics as markers since they require no radioactive isotopes and in addition, detect only a single locus. The development of a straightforward PCR protocol to check grape tissues potentially infected by $X$. fastidiosa causing PD is of fundamental importance to prevent spreading this pathogen in Brazil, by importing propagating plant materials from regions where this phytopathogen is endemic. In the course of previous studies on the genetic diversity between isolates of $X$. fastidiosa carried out in our laboratory, using the repetitive sequences REP, ERIC and BOXA amplified by PCR, it was possible to make a distinction between the $X$. fastidiosa isolated from grapevine and those isolated from plum, coffee and citrus.

As a result, a fragment of nearly $630 \mathrm{bp}$ was amplified by the REP-PCR and used as template for the construction of a specific oligonucleotide primer for detecting $X$. fastidiosa isolated from grapevines.

\section{MATERIALS AND METHODS}

\section{Bacterial strains and DNA extraction}

The $X$. fastidiosa strains used in this study are listed in Table 1. All $X$. fastidiosa strains were grown in PW broth medium (Davis et al., 1981) for six days on a rotatory shaker at $28^{\circ} \mathrm{C}$. The DNA samples of Escherichia coli (JM 83::pHT 408, MM 294, MM 294::pAMP and MM 294::pKAN), Xanthomonas axonopodis pv. citri (Hasse) Vanterin el al., Xanthomonas campestris pv. campestris (Hasse) Gabriel et $a l$. and Erwinia spp. used for the primer specificity tests were kindly supplied by Dr. Manoel V. F. Lemos (E. coli and Erwinia sp.) and Dr. Jesus A. Ferro (strains of Xanthonomas sp.). The genomic DNA extraction from the $X$. fastidiosa strains followed the method proposed by Ausubel et al. (1987) with some modifications, which included the addition of $100 \mu$ of RNAse solution $(200 \mu \mathrm{g} / \mathrm{ml})$ soon after the treatment with proteinase $\mathrm{K}$, and incubation at $37^{\circ} \mathrm{C}$ for $1 \mathrm{~h}$. The isolated DNA samples were used as template for standard PCR.

\section{PCR amplification procedure}

Repetitive sequence based-PCR technology (REPPCR) was used to identify unique PCR products for $X$. fastidiosa causing the PD. The DNA from $X$. fastidiosa strains were amplified with REP1-R (5'-IIIICGICGIATCCIGGC-3') and REP 2 (5'-ICGICTTATCIGGCCTAC-3') primers (Versalovic et al., 1991). The overall reactions were adjusted to a final volume of $20 \mu$, containing $1 \mathrm{X}$ PCR buffer (50 $\mathrm{mM} \mathrm{KCl}, 200 \mathrm{mM}$ Tris-HCl, pH 8,4), 2 mM MgCl, $200 \mu \mathrm{M}$ of each dNTP (Invitrogen, CA, USA), 1 U of Taq DNA polymerase (Invitrogen, CA, USA), $30 \mathrm{ng}$ of each primer (REP1-R and REP 2) and 50ng of template DNA. The reactions were then taken to a programmable thermocycler (MJ Research, Inc., model PTC $100^{\mathrm{TM}}$ ) using the following program: $94^{\circ} \mathrm{C}$ for 2 min; 35 cycles at $94^{\circ} \mathrm{C}$ for $1 \mathrm{~min}, 45^{\circ} \mathrm{C}$ for $1 \mathrm{~min}$ and $72^{\circ} \mathrm{C}$ for $1 \mathrm{~min}$ and $30 \mathrm{~s}$ for denaturation, annealing and extension; respectively, and a final extension step at $72{ }^{\circ} \mathrm{C}$ for $5 \mathrm{~min}$. The products were visualized in $1.5 \%$ agarose gels $1 \mathrm{X}$ TBE buffer containing $0.5 \mu \mathrm{g} / \mathrm{ml}$ ethidium bromide (Sambrook et al., 1989) and photographed using Gel-doc 1000 digital photodocumentation equipment (BioRad).

\section{Sequencing, data analysis and primer design}

After electrophoresis, a band of about $630 \mathrm{bp}$ in size from $X$. fastidiosa strain 8935 was cut out of the gel and the DNA recovered and purified using a Concert ${ }^{\mathrm{TM}}$ Gel extraction systems kit (Invitrogen, CA, USA). For sequencing, $4 \mu \mathrm{l}$ of the big dye terminator cycle sequencing ready reaction (PE Applied Biosystems, Foster City, CA, USA), 1.6 pmols of the primers REP1-R and REP 2, and $20 \mathrm{ng}$ of DNA from the purified fragment (not cloned) of the strain 8935 were used to set up a final $10 \mu \mathrm{l}$ volume sequencing reaction. The reactions were then performed at the same conditions previously described. After fragment precipitation and washing for removal of the ddNTPs unincorporated through sequencing reaction, the samples were sequenced on an ABI PRISM ${ }^{\mathrm{TM}}$ 377 automatic DNA sequencer (Applied Biosystems, Inc., Foster City, CA, USA). Sequenced data were analyzed using BLAST - Basic local alignment search tools (version 2.2) program (Altschul et al., 1997) through the network service of the National Center for Biotechnology Information (http:/ /www.ncbi.nlm.nih.gov). The OLIGO 4.0 software (National 
Development of a scar marker for Pierce's Disease...

TABLE 1 - Strains, hosts, geographic origin and source of Xylella fastidiosa

\begin{tabular}{|c|c|c|c|}
\hline Strain & Host & Geographic Origin & Source \\
\hline $\mathrm{OK}$ & Almond (Prunus amygdalus) & California, USA & - \\
\hline 6746 & Almond & Massachusetts, USA & ATCC $35870^{\circ}$ \\
\hline $9 \mathrm{a} 5 \mathrm{c}$ & Citrus (Citrus sinensis) & São Paulo, Brazil & INRA $^{\mathrm{a}}$ \\
\hline 10348 & Citrus & Paraná, Brazil & IAPAR $^{b}$ \\
\hline 10438 & Citrus & Paraná, Brazil & IAPAR $^{\mathrm{b}}$ \\
\hline 11037 & Citrus & São Paulo, Brazil & IAPAR $^{b}$ \\
\hline 11038 & Citrus & São Paulo, Brazil & IAPAR $^{b}$ \\
\hline 11066 & Citrus & Paraná, Brazil & IAPAR $^{b}$ \\
\hline 11067 & Citrus & Paraná, Brazil & IAPAR $^{b}$ \\
\hline 11347 & Citrus & Paraná, Brazil & IAPAR $^{b}$ \\
\hline 11348 & Citrus & Paraná, Brazil & IAPAR $^{b}$ \\
\hline 11380 & Citrus & Santa Catarina, Brazil & IAPAR $^{b}$ \\
\hline 11399 & Citrus & Sergipe, Brazil & IAPAR $^{b}$ \\
\hline 11400 & Citrus & Sergipe, Brazil & IAPAR $^{b}$ \\
\hline 11775 & Citrus & Rio Grande do Sul, Brazil & IAPAR $^{b}$ \\
\hline 11779 & Citrus & Santa Catarina, Brazil & IAPAR $^{b}$ \\
\hline 11834 & Citrus & Paraná, Brazil & IAPAR $^{b}$ \\
\hline B-14 & Citrus & São Paulo, Brazil & $\mathrm{CCSM}^{\mathrm{c}}$ \\
\hline CVC-5 & Citrus & São Paulo, Brazil & $\mathrm{CCSM}^{\mathrm{c}}$ \\
\hline M2-1 & Citrus & São Paulo, Brazil & $\mathrm{CCSM}^{\mathrm{c}}$ \\
\hline 12288 & Coffea (Coffea arabica) & Paraná, Brazil & IAPAR $^{b}$ \\
\hline 6748 & Elm (Ulmus americana) & Washington, USA & ATCC $35873^{\mathrm{d}}$ \\
\hline 6744 & Mulberry (Morus rubra) & Massachusetts, USA & ATCC $35868^{\mathrm{d}}$ \\
\hline 6745 & Mulberry & Massachusetts, USA & ATCC $35869^{\mathrm{d}}$ \\
\hline OF & Oak (Quercus rubra) & Florida, USA & - \\
\hline OG & Oak & Georgia, USA & - \\
\hline 12319 & Periwinkle wilt (Catharantus roseus) & - & - \\
\hline 6751 & Perinwinkle wilt & Florida, USA & ATCC $35878^{\mathrm{d}}$ \\
\hline 9746 & Plum (Prunus salicina) & Parana, Brazil & IAPAR $^{b}$ \\
\hline 6747 & Prunus & Georgia, USA & ATCC $35871^{\mathrm{d}}$ \\
\hline 6749 & Ragweed (Ambrosia americana) & Florida, USA & ATCC $35876^{\mathrm{d}}$ \\
\hline 8935 & Grapevine (Vitis vinifera) & Florida, USA & ATCC $35879^{\circ}$ \\
\hline 9713 & Grapevine & - & IAPAR $^{b}$ \\
\hline 6750 & Grapevine & California, USA & ATCC $35877^{d}$ \\
\hline 6752 & Grapevine & Florida, USA & ATCC $35879^{\mathrm{d}}$ \\
\hline 6753 & Grapevine & Florida, USA & ATCC $35881^{\mathrm{d}}$ \\
\hline 6068 & Grapevine & - & FTAT $^{\mathrm{e}}$ \\
\hline SLO & Grapevine & California, USA & \\
\hline
\end{tabular}

a-INRA, Institut National de la Recherche Agronomique et Université Victor Ségale, Bordeaux, France.; b-IAPAR, Instituto Agronômico do Paraná, Paraná, Brazil.; c-CCSM, Centro Apta Citros "Sylvio Moreira”, Instituto Agronômico, Cordeirópolis - São Paulo, Brazil.; d-ATCC, “American Type Culture Collection”, Manassas, Va.; e-FTAT, Fundação Tropical “André Tosello”, Campinas, Brazil.

Bioscience, Inc. Plymouth, MN) was used to design a $X$. fastidiosa $\mathrm{PD}$ specific 21-mer primer, herein denominated Xf1 (5'-CGGGGGTGTAGGAGGGGTTGT-3') and subsequently synthesized by BIO-SYNTHESIS Inc.

\section{SCAR amplification}

The SCAR amplifications of the genomic DNA samples were performed using $50 \mathrm{ng}$ of DNA template in $20 \mu \mathrm{l}$ reactions containing $1 \mathrm{X}$ PCR buffer $(50 \mathrm{mM} \mathrm{KCl}, 200 \mathrm{mM}$ Tris- $\mathrm{HCl}$, $\mathrm{pH}$ 8.4), $2 \mathrm{mM} \mathrm{MgCl}_{2}, 200 \mu \mathrm{M}$ each dNTP (Invitrogen, CA, USA), $1 \mathrm{U}$ of Taq DNA polymerase (Invitrogen, CA, USA), 30 ng each primer (Xf-1 and REP 2). The amplification was performed at the same conditions described before, except annealing was at $62{ }^{\circ} \mathrm{C}$ and the final step was for $10 \mathrm{~min}$. The products were visualized and photographed as described before.

\section{Accuracy of the oligonucleotides Xf-1/REP 2}

Twenty microliter of each product of a serial dilution of a cell suspension $\left(\mathrm{OD}_{600}=0.92\right)$ of the strain 8935 of $X$. fastidiosa in sterile «distilled» water was centrifuged and used to perform PCR, following the same protocol described before. Dilutions $(100 \mu \mathrm{l})$ were plated on PW medium. After 14 days of incubation at $28{ }^{\circ} \mathrm{C}$, colony-forming units $(\mathrm{CFU})$ were determined. 


\section{RESULTS AND DISCUSSION}

\section{Identification of a differential fragment of $X$. fastidiosa strain isolated from grapevine using REP-PCR}

The genetic diversity of 23 strains of $X$. fastidiosa isolated from four hosts plants (plum, coffee, citrus and grapevine) was analyzed by the amplification of repetitive extragenic palindromic sequences (REP) found in the bacterial genome (Figure 1). The molecular profiles obtained by the REP-PCR amplification showed three distinct groups among the $X$. fastidiosa strains. The first group was outlined only by $X$. fastidiosa isolated from citrus (9a5c, 11347, 10348, 10438, $11066,11067,11834,11380,11775$ and 11779), with amplifying fragments ranging from 300 to $4,000 \mathrm{bp}$. The second group was composed of seven strains of $X$. fastidiosa from citrus (11037, 11038, B-14, M2-1, 11399, 11400, CVC-5) and one from coffee trees (12288). The distinction of this group was possible due to the presence of a $300 \mathrm{bp}$ amplified fragment. The third group, comprised of strains from grapevine (8935 and 9713) and plum (9746), showed a sufficiently distinct profile from the others, with a 630-bp fragment (Figure 1). The strain 11348 from citrus (line 12) showed a unique profile, differing from the three groups here analyzed. Differences among strains of $X$. fastidiosa isolated from sweet orange [Citrus sinensis (L.) Osbeck] and coffee (Coffea arabica L.) trees with symptoms of citrus variegated chlorosis and coffee leaf scorch, respectively, were not detected, using the REP1-R and REP 2 oligonucleotides (Qin et al., 2001). The 630-bp product, only amplified from the grapevine strains, could be used to develop a SCAR marker suitable for amplifying specifically strains of $X$. fastidiosa causing PD.

\section{Conversion of a REP-PCR marker into a SCAR marker}

The 630-bp fragment was purified and sequenced from both ends (GenBank - http://www.ncbi.nlm.nih.gov and access number AY593993). The sequence was compared with those already present in the Genomic Data Bank (GenBank - http://www.lbi.ic.unicamp.br) using the BLASTx, a subprogram of BLAST (Altschul et al., 1997), which compares nucleotide sequences with protein sequences. Similarities were verified between $X$. fastidiosa strain 9a5c from citrus (Simpson et al., 2000) and Temecula strain from grapevine (Van Sluys et al., 2003) with scores and e-values of 259 and $7 \mathrm{e}^{-71}$ and 280 and $4 \mathrm{e}^{-77}$, respectively. The 630 -bp fragment is present in the intergenic spacer of the $X$. fastidiosa strain 9a5c, covering the ORFs (Open Reading Frame) XF2486 and XF0726 (access number NP 298016) which codifies a hypothetical protein whereas in the "Temecula-1" strain this sequence is present in ORF PD 1095 (access number gi|28197945), which codifies a conserved hypothetical protein.

The Xf-1 oligonucleotide was designed, with $66.7 \%$ CG content, limited to the positions 290 to $311 \mathrm{bp}$. It was used jointly with the REP-2 primer to check the $X$. fastidios $a$ DNAs isolated form a wide number of host plants (Figures 2 and 3). The amplification yielded a fragment about $350 \mathrm{pb}$. Concentrations of 50 and $100 \mathrm{ng}$ of DNA samples were tested to optimize PCR conditions. Both DNA concentrations produced indistinguishable amplification fragments for all DNA samples (data not shown). Assays were carried out using four annealing temperatures $\left(50,52,55\right.$ and $\left.62^{\circ} \mathrm{C}\right)$. A fragment about 350 bp was positively amplified for all $X$. fastidiosa isolates at 50,52 and $55^{\circ} \mathrm{C}$. However it was present only for the grapevine strains at $62{ }^{\circ} \mathrm{C}$, indicating the primers specificity. Pooler \& Hartung (1995) observed that low annealing temperatures resulted in the amplification of identical RAPD bands for all analyzed $X$. fastidiosa strains, including other bacterial strains as well. The Xf-1/REP 2 primer pair showed specificity towards $X$. fastidiosa isolated from grapes and no amplification was observed for the other $X$. fastidiosa strains from almond (Prunus amygdalus Batsch), coffee, elm (Ulmus americana L.), mulberry (Morus rubra L.), periwinkle (Catharantus roseus L.), plum (Prunus salicina Lindl), oak (Quercus rubra L.), ragweed (Ambrosia artemisiifolia L.), and Erwinia sp., E. coli, X. axonopodis pv. citri and $X$.

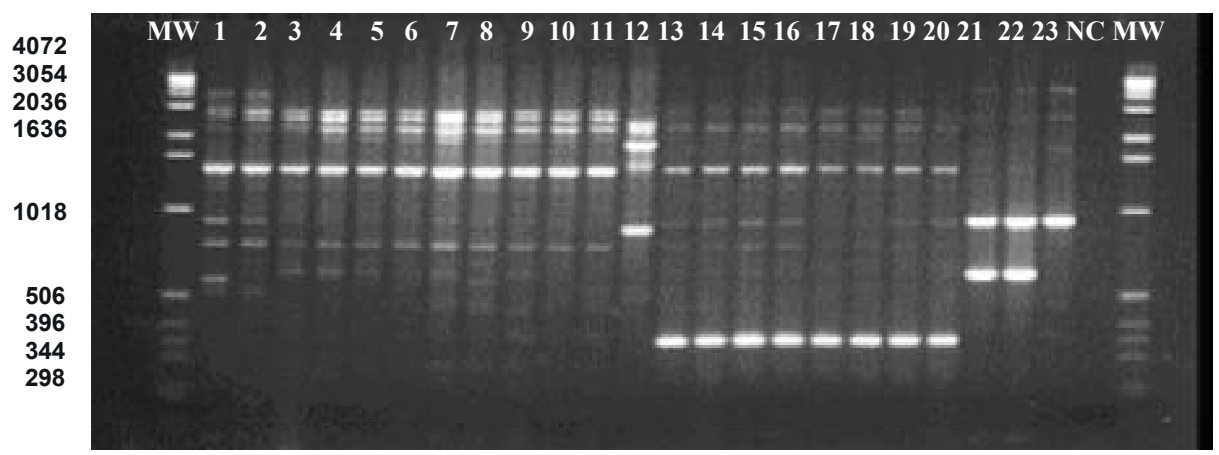

FIG. 1 - Agarose gel electrophoresis of PCR products with primers REP1-R/REP 2 using Xylella fastidiosa from different host plants. NC: Negative Control, MW: standard molecular weight of 1 Kb DNA ladder (Invitrogen), 1-19: citrus (Citrus sinensis) 31b9a5c, 31b9a5c, 11347, 10348, 10438, 11066, 11067, 11834, 11380, 11775, 11779, 11348, 11037, 11038, B14, M2-1, 11399, 11400, CVC-5 respectively, 20: coffee (Coffea arabica) 12288, 21-22: grapevine (Vitis vinifera) 8935 and 9713 and 23: plum (Prunus salicina) 9746. 
Development of a scar marker for Pierce's Disease..

campestris pv. campestris (Figures 2 and 3). This SCAR fragment generated by Xf-1/REP 2 was not observed for the other bacterial strains tested such as: Bacillus thuringiensis, Bradyrhizobium elkanii, Bradyrhizobium japonicum, Staphylococcus aureus, Staphylococcus sp. (data not shown).

\section{Sensitivity of Xf-1/REP-2 primers}

The $350 \mathrm{bp}$ fragment was detected up to a dilution of 1 $\mathrm{x} 10^{-5}$, corresponding to $130 \mathrm{CFU} / \mathrm{ml}$. However, only $20 \mu \mathrm{l}$ were added to the PCR mix, allowing the detection of 1-3 CFU. Due to the sensitivity of the Xf-1/REP 2 primers, they could be useful in the bio-PCR technique by speeding up identification of plant material infected by this phytopathogenic organism. Our results encourage the application of this PCR-based identification method in setting up a reliable diagnostic assay for detection of $X$. fastidiosa in grapevines grown in Brazil.

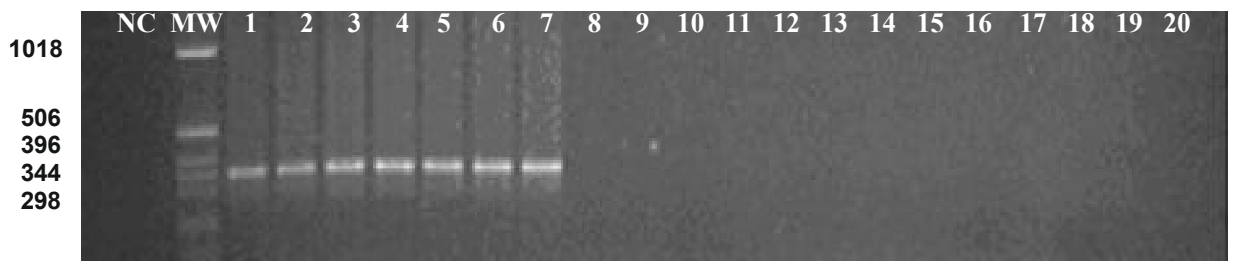

FIG. 2 - Agarose gel electrophoresis of PCR products with primers Xf-1/REP 2. NC: Negative Control, MW: standard molecular weight of $1 \mathrm{~Kb}$ DNA ladder (Invitrogen); 1-7: grapevine (Vitis vinifera) 8935, 9713, 6068, 6750, 6752, 6753 and SLO, 8-9: citrus (Citrus sinensis) 9a5c and 11400, 10-11: mulberry (Morus rubra) 6744 and 6745, 12: almond (Prunus amygdalus) 6746, 13: plum (Prunus salicina) 6747, 14: elm (Ulmus americana) 6748, 15: ragweed (Ambrosia artemisiifolia) 6749, 16: perwinkle (Catharantus roseus) 6751, 17: coffee (Coffea arabica) 12888, 18: almond OK, 19-20: oak (Quercus rubra) OG and OF.

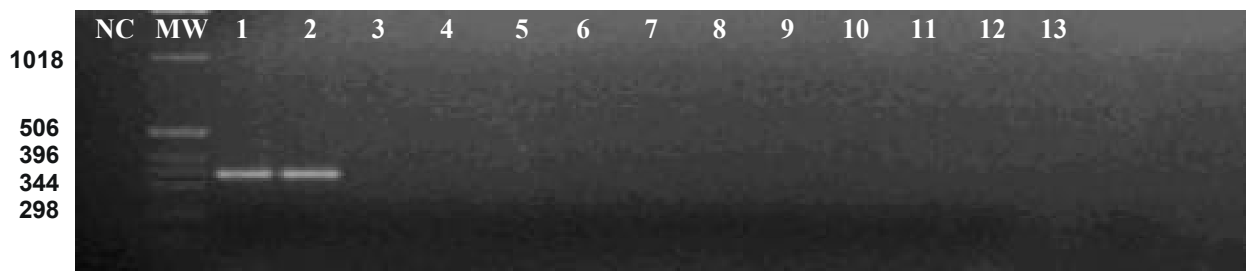

FIG. 3 - Agarose gel electrophoresis of PCR products with primers Xf-1/REP 2. NC: Negative Control, MW: standard molecular weight of $1 \mathrm{~Kb}$ DNA ladder (Invitrogen), 1-2: grapevine (Vitis vinifera) 8935 and 9713, 3: plum (Prunus salicina) 9746, 4: coffee (Coffea arabica) 12888, 5: almond (Prunus amygdalus), 6: Xanthomonas axonopodis, 7-8: X. campestris, 9-12: Escherichia coli JN, MM, pAMP, pKAN and 13: Erwinia sp.

\section{ACKNOWLEDGMENTS}

This research was supported in part by FAPESP. We would like to thank the following colleagues: Dr. A. H. Purcell, Dr. M. V. F. Lemos, Dr. Marcos A. Machado and Dr. Rui Pereira Leite Junior for supplying the bacterial strains.

\section{LITERATURE CITED}

ALTSCHUL S.F., MADDEN, T.L., SCHAFFER, A.A., ZHANG, J.H., ZHANG, Z., MILLER, W. \& LIPMAN, D.J. Gapped BLAST and PSI-BLAST: a new generation of protein database search programs. Nucleic Acids Research 25:3388-3402. 1997.

AUSUBEL, F.M., BRENT, R., KINGSTON, R.E, MOORE, D.D., SEIDMAN, J.G., SMITH, J.A. \& STRUHL, K. Current Protocols in Molecular Biology. New York. John Wiley \& Sons Inc. 1987. CHANG, C.J., GARNIER, M., ZREIK, L., ROSSETTI, V. \& BOVÉ, J.M. Culture and serological detection of the xylem-limited bacterium causing citrus variegated chlorosis and its identification as a strain of Xylella fastidiosa. Current Microbiology 27:137-142. 1993.

CHEN, J., CHANG, C.J., JARRET, R.L. \& GAWEL, N. Genetic variation among Xylella fastidiosa strains. Phytopathology 82:973977. 1992.

COLETA-FILHO, H.D., TAKITA, M.A., SOUZA, A.A., VILDOSO, C.I.A. \& MACHADO, M.A. Differentiation of strains of Xylella fastidiosa by a variable number of tandem repeat analysis. Applied Environmental Microbiology 67:4091-4095. 2001.

COSTA, P.I., FRANCO, C.F., MIRANDA, V.S., TEIXEIRA, D.C., HARTUNG, J.S. Strains of Xylella fastidiosa rapidly distinguised by Arbitrarily Primed-PCR. Current Microbiology 40:279-282. 2000. 


\section{R.F. Travensolo et al.}

DAVIS, M.J., FRENCH, W.J. \& SCHAAD, N.W. Axenic culture of the bacteria associated with phony disease of peach and plum leaf scald. Current Microbiology 6:309-314. 1981.

HENDSON, M., PURCELl, A.H., CHEN, D., SMART, C., GUILHABERT, M. \& KIRKPATRICK, B. Genetic diversity of Pierce's disease strains and other pathotypes of $X$. fastidiosa. Applied and Environmental Microbiology 67:895-903. 2001.

HOPKINS, D.L. Xylella fastidiosa: Xylem-limited bacterial pathogen of plants. Annual Review Phytopathology 22:271-290. 1989.

KARP, A., SEBERG, A. \& BUIATTI, M. Molecular techniques in the assessment of botanical diversity. Annual Botany 78:143-149. 1996.

POOLER, M.R. \& HARTUNG, J.S. Genetic relationships among strains of Xylella fastidiosa based on RAPD-PCR data. Current Microbiology 31:134-137. 1995.

PURCELL, H. A \& HOPKINS, D.L. Fastidious xylem-limited bacterial plant pathogens. Annual Review Phytopathology 34:131151. 1996.

QIN, X., MIRANDA, V.S., MACHADO, M.A., LEMOS, E.G.M. \& HARTUNG, J.S. An evaluation of the genetic diversity of Xylella fastidiosa isolated from diseased citrus and coffee in São Paulo, Brazil. Phytopathology 91:599-603. 2001.

ROSSETTI, V., GARNIER, M., BOVE, J.M., BERETTA, M.J.G., TEIXEIRA, A.R.R., QUAGGIO, J.A. \& DE NEGRI, J.D. Présence de bactéries dans le xylème d'orangers atteints de chlorose variégée, une nouvelle maladie des agrumes au Brésil. C. R. Académie des Sciences 30:345-349. 1990.

SAMBROOK, J., MANIATIS, T. \& FRITSCH, E.F. Molecular Cloning: A Laboratory Manual. Cold Spring Harbor Laboratory Press, New York. 1989.

SIMPSON, A.J.G., REINACH, F.C., ARRUDA, P., ABREU, F.A., ACENCIO, M., ALVARENGA, R., ALVES, L.M.C. et al. The genome sequence of the plant pathogen Xylella fastidiosa. Nature 406:151-159. 2000

VAN SLUYS, M.A., OLIVEIRA, M.C., MONTEIRO-VITORELLO, C.B., MIYAKI, C.Y., FURLAN, L.R., CAMARGO, L.E.A., DA SILVA, A.C.R., MOON, D.H., TAKITA, M.A., LEMOS, E.G.M et al. Comparative analysis of complete genome sequence of Pierce's Disease and Citrus Variegated Chlorosis strains of Xylella fastidiosa. Journal of Bacteriology 185:1018-1026. 2003.

VERSALOVIC, J., KOEUTH, T. \& LUPSKI, J.R. Distribution of repetitive DNA sequences in eubacteria and application to fingerprinting of bacterial genomes. Nucleic Acids Research 19:6823-6831. 1991.

WELLS, J.M., RAJU, B.C., JUNG, H.Y., WEISBURG, W.G., MANDELCO-PAUL, L. \& BRENNER, D.J. Xylella fastidiosa gen nov., sp. nov. gram-negative, xylem-limited fastidious plant bacteria related to Xanthomonas spp. International Journal of Systematic Bacteriology 37:136-143. 1987. 